\title{
CYTOTOXIC T CELL ADJUVANT EFFECTS OF THREE SALMONELLA ENTERICA FLAGELLINS
}

\author{
Catarina J.M. Braga ${ }^{1 \#}$; Liliana M. Massis ${ }^{1 *}$; Bruna C.G. Alencar ${ }^{2}$; Maurício M. Rodrigues² ${ }^{2}$ M.E. Sbrogio-Almeida ${ }^{3}$; \\ Luís C.S. Ferreira ${ }^{1 *}$
}
${ }^{1}$ Departmento de Microbiologia, Instituto de Ciências Biomédicas, Universidade de São Paulo, São Paulo, SP, Brasil; ${ }^{2}$ Cintergen, Universidade Federal de São Paulo, São Paulo, SP, Brasil; ${ }^{3}$ Divisião de Produção e Desenvolvimento Tecnológico, Instituto Butantan, São Paulo, SP, Brasil.

Submitted: August 03, 2007; Returned to authors for corrections: October 17, 2007; Approved: January 21, 2008.

\begin{abstract}
Bacterial flagellins are important virulence-associated factors and strong inducers of inflammatory responses in mammalian hosts. Flagellins have also been investigated as potential vaccine adjuvants, either for induction of humoral or cellular immune responses, to different target antigens. In this study we investigated the adjuvant properties of three Salmonella enterica flagellins types ( $\mathrm{FliC} d, \mathrm{FliC} i$ and $\mathrm{FljB}$ ) to an ovalbuminderived $\mathrm{CD} 8^{+} \mathrm{T}$ cell-restricted epitope $\left(\mathrm{OVA}_{257-264}\right)$. Although mice immunized with the three tested flagellins elicited antigen-specific activated $\mathrm{CD} 8^{+} \mathrm{T}$ cells, only animals immunized with $\mathrm{FliC} i$ and $\mathrm{FliC} d$ flagellins admixed with ovalbumin mounted specific in vivo cytotoxic responses to peptide-pulsed target cells. The present results indicate that Salmonella flagellins are endowed with type-specific adjuvant effects toward murine $\mathrm{CD}^{+} \mathrm{T}$ cells, a feature that may impact their use as adjuvants for prophylatic or therapeutic vaccines.
\end{abstract}

Key words: Salmonella, flagellin, cytotoxic T cells, adjuvants, vaccines.

\section{INTRODUCTION}

Flagellin, the structural subunit of flagellar filaments, contribute to the virulence of different pathogenic bacteria and promote activation of inflammatory responses in different mammalian hosts (17). The strong immunological effects of bacterial flagellins are mediated mainly by the specific binding to the toll-like receptor 5 (TLR 5) leading to signal transduction cascades that culminate with activation of transcription factors, production of pro-inflammatory mediators and activation of different cell types including antigen presenting cells (APC) such as macrophages and dendritic cells $(13,20)$. Indeed, the immunomodulatory behavior of bacterial flagellins has also been explored as a potential vaccine adjuvant both for induction of specific humoral and cellular immune responses $(4,7,9,11)$.

Salmonella enterica strains produce diseases ranging from mild enteritis to severe systemic infections in different animal hosts according to the specific strain serovar. Most Salmonella strains, such as $S$. enterica serovar Typhimurium ( $S$.
Typhimurium), are characterized by the phase variation phenomenon in which controlled expression of two or more flagellin-encoding genes results in the expression of alternate flagellar antigens, initially named as phase $1(H I)$ and phase 2 (H2) flagellins but presently recognized as FliC and FljB flagellins, respectively (8). The variable nature of FliC and FljB flagellins together with the multiple lipopolyssacharide sidechains (O antigens), define more than 2,000 recognized Salmonella serovars (5). The natural diversity of Salmonella flagellins reflects mainly the polymorphism at the central portion of the protein, which creates sub-types such as illustrated by FliC flagellins expressed by $S$. Typhimurium (FliCi), $S$. Typhi (FliCd) and $S$. Muenchen (FliCd (6).

Although several reports have investigated the adjuvant effects of specific Salmonella flagellins $(4,7,11,16)$ a comparison of the adjuvant effects of different Salmonella flagellin types to $\mathrm{CD} 8^{+} \mathrm{T}$ cells have not been reported so far. Therefore, the objective of the present study was the investigation of the adjuvant effects of three Salmonella

*Corresponding Author. Mailing address: Department of Microbiology-ICB, University of São Paulo, Av. Prof. Lineu Prestes, 1374, São Paulo, SP 05008-000, Brasil. Tel.: +5511-30917338. E-mail: 1csf@usp.br

\#Both authors contributed equally to the present study. 
enterica flagellins, including two expressed by $S$. Typhimurium (FliC $i$ and $\mathrm{FljB}$ ) and one originally encoded by $S$. Muenchen (FliCd), toward a $\mathrm{CD} 8^{+} \mathrm{T}$ cell-specific epitope derived from ovalbumin. The results indicated that, although the three tested flagellin types activated antigen-specific $\mathrm{CD} 8^{+} \mathrm{T}$ cells, in vivo cytotoxic effects were elicited only in mice immunized with the FliC $i$ and FliC $d$ flagellins.

\section{MATERIALS AND METHODS}

\section{Bacterial strains and growth conditions}

$S$. Typhimurium SL3201 derivative strains were generated following insertion of transposons in fliCi $($ fliC::Tn10) or $f l j B$ (fljB::MudJ) genes (19). These strains produced only $\mathrm{FliC} i$ (phase 1) or FljB (phase 2) flagellins and were kindly supplied by Dr. Alison D. O'Brien at the University of the Health Sciences, Bethesda, Maryland, USA. S. Dublin SL5930 expressed a plasmid-encoded FliC $d$ flagellin, originally derived from $S$. Müenchen, as previously described (14). $S$. Typhimurium and $S$. Dublin strains were routinely cultivated at $37^{\circ} \mathrm{C}$ for $6 \mathrm{~h}$ in Luria-Bertani (LB) broth (Difco Laboratories) supplemented with antibiotic under aerobic conditions (200 rpm in an orbital shaker) for flagellin extractions.

\section{Purification of Salmonella flagellins}

Flagellins expressed by $S$. Typhimurium (FljB or $\mathrm{FliC} i$ ) and $S$. Muenchen (FliC $d$ ) were routinely extracted from $50 \mathrm{ml}$ cultures. Cells were collected by centrifugation, suspended in $2 \mathrm{~mL}$ of phosphate-buffered saline ( $\mathrm{pH} 7.4)$ and sheared for 2 min in bench mixer (Genie 2) at maximal speed. Cells were kept in ice bath for $1 \mathrm{~min}$ and the procedure was repeated 3 times. The cell suspensions were then centrifuged at $10,000 \mathrm{X} \mathrm{g}$ for $10 \mathrm{~min}$ to remove the bacterial cells. The culture supernatants containing the sheared flagellins were precipitated with acetone, the resulting pellet suspendered in PBS and, finally, submitted to heat treatment $\left(65^{\circ} \mathrm{C}\right.$ for $\left.30 \mathrm{~min}\right)$ to depolymerize the filaments into flagellin monomers. Protein concentration was determined using BCA assay (Pierce) and protein purity checked by SDS-PAGE. Removal of contaminating lipopolysaccharide was accomplished with Detoxi-Gel column in according to the manufacturer's instructions (Pierce). Endotoxin levels were determined using the Chromogenic Limulus Amebocyte Lysate assay (Cambrex Bio Science) as directed by the manufacturer. The determined endotoxin concentrations in the purified flagellin preparations were always bellow $0.125 \mathrm{EU} / \mu \mathrm{g}$.

\section{SDS-PAGE and immunoblot analyses}

SDS-PAGE was performed following standard procedures using a Mini Protean II vertical electrophoresis unit (Bio-Rad). Proteins sorted in $12 \%$ polyacrylamide gels were strained with Comassie Blue or transferred to nitrocellulose sheets $(0.45 \mu \mathrm{m}$ pore size) at $200 \mathrm{~mA}$ for $1 \mathrm{~h}$. After overnight blocking with $1 \%$ $(\mathrm{w} / \mathrm{v})$ bovine serum albumin (BSA) in phosphate-buffered saline (PBS) at $4^{\circ} \mathrm{C}$, nitrocellulose sheets were developed for reactive protein bands with different antibodies, according to previously published procedures (18).

\section{Immunization regimens}

Female C57BL/6 mice at 8 to 12 weeks of age were supplied by the Isogenic Mouse Breeding Facility of the Department of Parasitology, Institute of Biomedical Sciences, São Paulo University (USP). All procedures were carried out in accordance with the principles of the Brazilian code for the use of laboratory animals and were approved by the Ethics Committee on Use of Laboratory Animals from the Institute of Biomedical Sciences, USP. Animals were immunized with sterile phosphate buffered saline (PBS), ovalbumin (OVA) $(12 \mu \mathrm{g})$ (Sigma-Aldrich) alone or with each purified $\mathrm{FliC} d$, FliC $i$ or FljB flagellins $(5 \mu \mathrm{g})$. All immunizations were administered subcutaneously (s.c.) in a 100 $\mu \mathrm{l}$ volume on days 0 and 21 . Antigen-specific $\mathrm{T}$ cell responses were evaluated seven days after immunization.

\section{Antigen-specific ELISPOT assays}

The ELISPOT assay for quantification interferon-gamma (IFN- $\gamma$ ) producing cells was performed essentially as described earlier $(7,10,12) . \mathrm{CD}^{+} \mathrm{T}$ cells $\left(10^{6}\right)$ recovered from spleens immunized animals were added to microplate wells (MultiScreen, Millipore), previously coated with $10 \mu \mathrm{g} / \mathrm{mL}$ antiIFN $\gamma$ capture antibody (BD Pharmingen) diluted in PBS. CD8 ${ }^{+}$ $\mathrm{T}$ cells were enriched (>97\%) using magnetic beads on an AutoMacs cell separator ( Miltenyi Biotec,). T cells were then incubated overnight with naive antigen presenting cells $\left(10^{5}\right.$ cells/well) in the absence or presence of the OVA-derived $\mathrm{H}$ $2 \mathrm{~K}^{\mathrm{b}}$ restricted synthetic nonapeptide $\mathrm{OVA}_{254-267}$ (SIINFEKL), purchased at PSL (Heidelberg, Germany) and employed at a final concentration of $0.5 \mu \mathrm{g} / \mathrm{ml}$. Anti-CD3 (BD Pharmingen) was used as a positive control at a final concentration of 0.25 $\mu \mathrm{g} / \mathrm{ml}$. Plates were incubated overnight at $37^{\circ} \mathrm{C}$ in the presence of $5 \% \mathrm{CO}_{2}$. After incubation, the cells were washed and incubated with $2 \mu \mathrm{g} / \mathrm{mL}$ of biotinylated anti-mouse IFN- $\gamma$ (BD Pharmingen) diluted in PBS and 0.05\% Tween 20 (PBS-T). Plates were washed and incubated with streptoavidin peroxidase conjugate (Sigma) diluted 1:800 in PBS. Spot development was performed as previously described (12). Antigen-specific response was performed in duplicate and quantified using an automated ImmunoScan reader (Cellular Technology Ltd.). Data is represented as the number of IFN- $\gamma$ secreting cells $/ 10^{6}$ cells.

\section{In vivo cytotoxicity assays}

Splenocytes from naive mice were stained with $1 \mu \mathrm{M}$ or 10 $\mu \mathrm{M}$ of carboxyfluorescein diacetate succinimidyl ester (CFSE) (Invitrogen). The cells labeled with $10 \mu \mathrm{M}$ CFSE were pulsed 
for $40 \mathrm{~min}$ at $37^{\circ} \mathrm{C}$ with $1 \mu \mathrm{M}$ of the $\mathrm{OVA}_{254-267}$ peptide. Another cell aliquot was labeled with $1 \mu \mathrm{M}$ CFSE but was not pulsed with the target peptide. Both cells populations were transferred i.v. $\left(2 \times 10^{7}\right.$ cells/each) to immunized mice. One day later, spleens were isolated and the two cell populations were monitored by flow cytometry in a multivariant FACScan analyser (FACSCalibur, BD Biosciences). The percentages of target specific cell killing were determined as previously described $(2,21)$.

\section{Cytokine ELISA}

Aliquots containing $10^{7}$ spleens cells were cultured overnight with or without the $\mathrm{OVA}_{254-267}$ peptide. The culture supernatants were colleted after $48 \mathrm{~h}$ and stored at $-80^{\circ} \mathrm{C}$ until testing. IFN- $\gamma$ concentration were determined by sandwich ELISA using duplicate samples and a specific kit, according to instructions of the manufacturer (BD Pharmingen).

\section{Statistic analysis}

The data were analyzed by one-way ANOVA test. Values of $p<0.05$ were considered to be statistically significant.

\section{RESULTS}

The adjuvant effects of the three tested Salmonella flagellins (FliC $d$, FliC $i$ and $\mathrm{FljB}$ ) were evaluated with purified proteins extracted from two recombinant monophasic $S$. Typhimurium strains and one recombinant $S$. Dublin strain expressing a plasmid-encoded $S$. Muenchen FliCd flagellin (Fig. 1). Each purified flagellin was admixed with OVA and s.c. delivered in two doses to C57BL/6 mice. The OVA-specific T-cell responses were measured in ELISPOT assays using the $\mathrm{H}-2 \mathrm{~K}^{\mathrm{b}}$-restricted $\mathrm{CD} 8$ epitope $\left(\mathrm{OVA}_{257-264}\right)$ and purified $\mathrm{CD} 8^{+} \mathrm{T}$ cells derived from spleens of vaccinated mice. The results indicated that the three

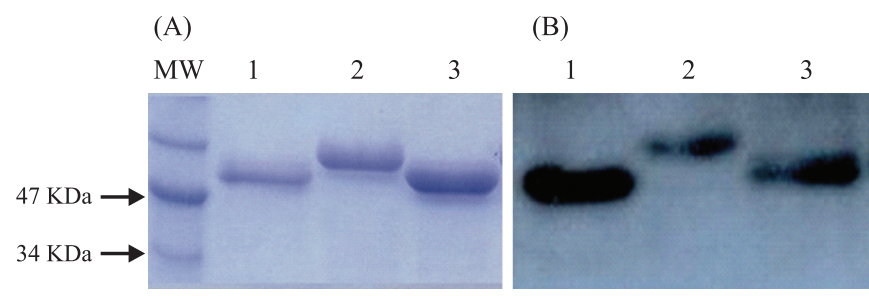

Figure 1. Extraction of native flagellins from Salmonella enterica strains. Protein samples were sorted in polyacrylamide gels were stained with Comassie Blue (A) or submitted to immune detection in Western blots (B) with anti-flagellin antibodies. Samples: MW- molecular weight markers; lane 1: FliCi flagellin harvested from $S$. Typhimurium; lane 2: FljB flagellin harvested from $S$. Typhimurium; lane 3: FliC $d$ flagellin harvested from $S$. Dublin SL5930 strain. tested Salmonella flagellins activated OVA-specific T-cells responses, such as measured by the number of antigen-specific IFN- $\gamma$-secreting $\mathrm{CD}^{+} \mathrm{T}$ cells (Fig. 2). The numbers of activated $\mathrm{CD} 8^{+} \mathrm{T}$ cells in mice immunized with OVA admixed with one of the three tested flagellins were not statistically significant among them. These results indicated that the three tested Salmonella flagellins are endowed with similar adjuvant effects toward immune responses mediated by activated antigenspecific $\mathrm{CD}^{+} \mathrm{T}$ cells, as measured by the number of IFN- $\gamma$ secreting cells in ELISPOT assays.

We also measured the secretion of IFN- $\gamma$ by spleen cells recovered from mice immunized with OVA and one of the three tested Salmonella flagellins. As indicated in Fig. 3, the amount of IFN- $\gamma$ produced by cells derived from mice immunized with FliC $d$ and stimulated with the $\mathrm{OVA}_{254-267}$ peptide was higher than

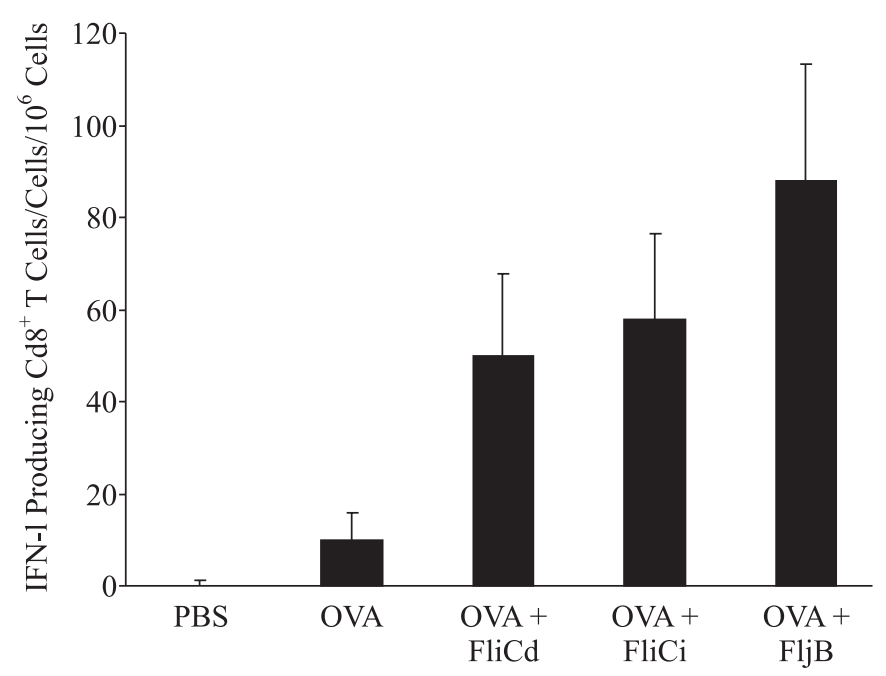

Figure 2. Induction of $\mathrm{CD}^{+} \mathrm{T}$ responses in mice immunized with OVA and different Salmonella flagellins using IFN- $\gamma$ ELISPOT assays. OVA-specific responses were determined with purified $\mathrm{TCD} 8^{+}$cells harvested from spleens of vaccinated C57BL/6 mice. The animals were inoculated with sterile PBS, OVA, OVA plus FliC $d$ flagellin (OVA + FliCd), OVA plus FliC $i$ flagellin (OVA+ FliCi) or OVA plus FljB flagellin (OVA + FljB). The values indicate the number of antigen-specific IFN- $\gamma$ producing cells per $10^{6}$ spleen cells following stimulation with the synthetic SIINFEKL peptide. Data depict the mean \pm SD of four mice/group performed in duplicate wells. Similar results were obtained in two independent experiments. The results obtained in mice immunized with the Salmonella flagellins were statistically different from those observed in mice immunized with OVA alone. No statistical difference was observed among the mice groups immunized with the tested Salmonella flagellins. 


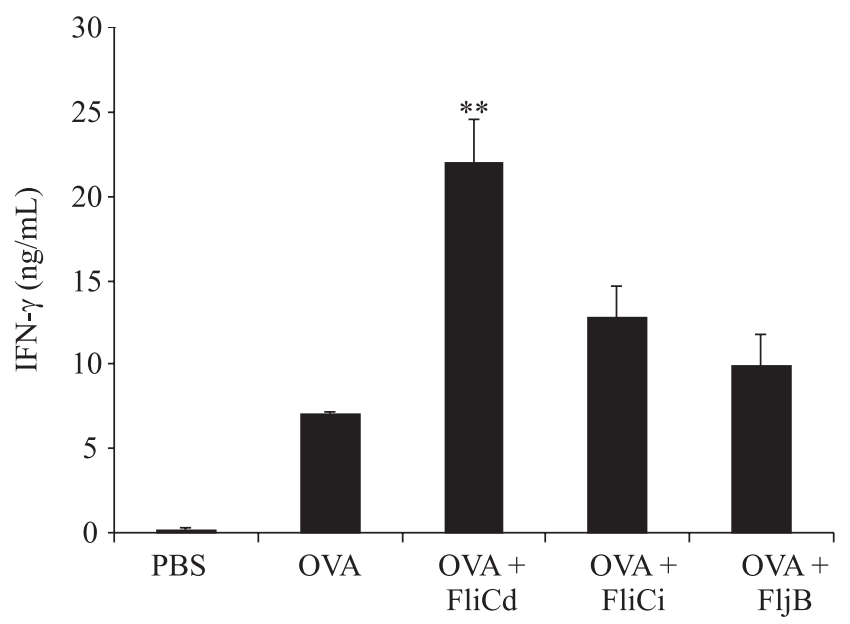

Figure 3. Induction of $\mathrm{CD}^{+} \mathrm{T}$ responses in mice immunized with OVA and different Salmonella flagellins using the secreted IFN- $\gamma$ ELISA assay. The IFN- $\gamma$ production was measured in supernatants of cultures prepared with total spleen cells harvested from mice immunized with PBS, OVA, OVA plus FliC $d$ flagellin, OVA plus FliC $i$ flagellin or OVA plus FljB flagellin and stimulated with synthetic SIINFEKL peptide for $48 \mathrm{~h}$. The data are representatives of results from two experiments carried out in duplicate $(* *$, statistical significant difference when compared to mice immunized with OVA, $p<0.01$ ).

those detected in cells derived from mice immunized with $\mathrm{FliC} i$ or FljB flagellins. The in vivo activities antigen-specific CD8 ${ }^{+} \mathrm{T}$ cell response were determined following inoculation of CFSElabeled $\mathrm{OVA}_{254-267}$ - pulsed cells into in mice immunized with OVA admixed with different Salmonella flagellins. The results presented in Fig. 4 shows that mice immunized with OVA and FliC $d$ or FliC $i$ flagellins elicited similar activation of antigenspecific $\mathrm{CD} 8^{+} \mathrm{T}$ cell-dependent cytotoxic responses. In contrast, mice immunized with OVA and FljB did not induce any significant specific cellular lysis, as measured in vivo cytotoxicity assay (Fig. 4). This result indicates that the tested Salmonella flagellins expressed differential adjuvant effects toward cytotoxic responses mediated by $\mathrm{CD} 8^{+} \mathrm{T}$ cells.

\section{DISCUSSION}

In spite of the enormous impact of vaccines in the control, and eventually eradication, of infectious disease vaccines are still not available for many of infectious diseases that still scourge millions of people around the world. Diseases associated with invasive pathogens require activation of strong $\mathrm{T}$ cell responses for the complete and sustained eradication of the pathogen, a feature not usually achieved by the presently available subunit vaccine formulations. The

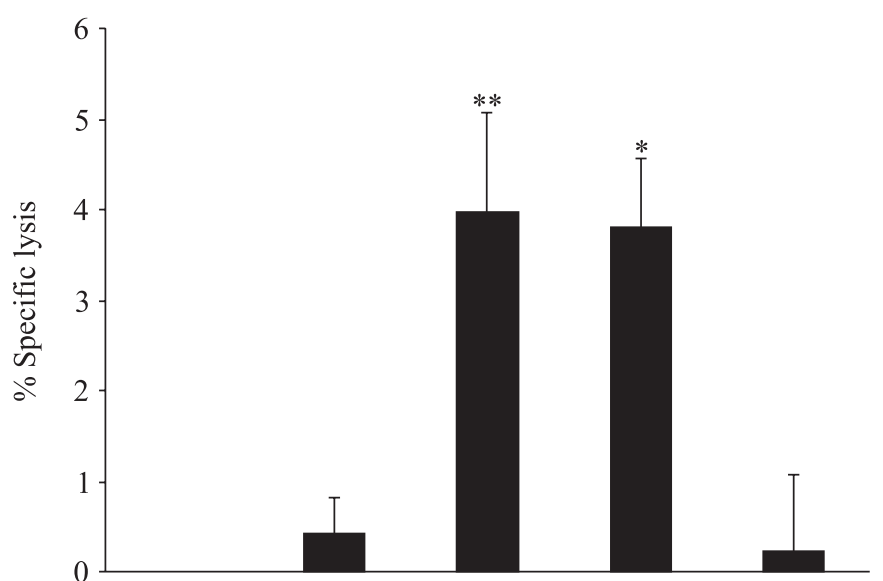

Figure 4. In vivo cytotoxic $\mathrm{CD} 8^{+} \mathrm{T}$ responses in mice immunized with OVA and different Salmonella flagellins. Seven days postimmunizations, CFSE-labeled $\mathrm{OVA}_{254-267}$ pulsed cells were i.v. administered to mice immunized with PBS, OVA, OVA plus FliC $d$ flagellin, OVA plus FliC $i$ flagellin or OVA plus FljB flagellin. Target cells were harvested 20h later and analyzed for CFSE fluorescence, as described in the methods section. Numbers represent the percentage of specific target cell lysis. Data depict the mean $\pm \mathrm{SD}$ of four mice/group. Asterisks indicate significant differences with regard to the value detected in mice immunized only with OVA $\left(*, p<0.05\right.$ and $\left.{ }^{* *}, p<0.01\right)$.

discovery of mammalian Toll-like receptors (TLR) and their corresponding microbial agonists, has opened up renewed perspectives for the development of alternative adjuvants modulating the desired type of immune responses including more effective activation of $\mathrm{CD} 8^{+} \mathrm{T}$ cell-dependent responses. In the present study, we investigated the differential adjuvant effects of TLR5-specific ligands, three Salmonella enterica flagellins, with regard to activation of specific $\mathrm{CD} 8^{+} \mathrm{T}$ cell responses. The present data indicate that, although all tested flagellins can elicited $\mathrm{CD} 8^{+} \mathrm{T}$ cell responses in vaccinated mice, only mice immunized with FliC flagellins elicited significant in vivo cytotoxic responses.

The results based on ELISPOT assays demonstrated that the three tested flagellins types activate similar OVA-specific $\mathrm{CD} 8^{+} \mathrm{T}$ cell responses, further confirming the previously reported adjuvant effects of bacterial flagellins on either $\mathrm{CD} 4^{+}$ and $\mathrm{CD} 8^{+} \mathrm{T}$ lymphocytes $(4,7,9,11,18)$. However, detection of secreted IFN- $\gamma$ by spleen cells incubated with the $\mathrm{CD} 8^{+}$ restricted $\mathrm{OVA}_{254-267}$ peptide indicated that mice immunized with OVA and FliC $d$ developed enhanced $\mathrm{CD} 8^{+} \mathrm{T}$ cell responses with regard to mice immunized with OVA admixed with FliC $i$ or FljB as vaccine adjuvants.

The differential adjuvant effect of the tested Salmonella flagellins was further supported by the in vivo cytotoxic 
responses. In contrast to the ELISPOT results, in which the three tested flagellins exhibited a similar behavior, only the two FliC flagellins exerted a clear adjuvant effect to the cytotoxic responses toward target cells pulsed with the $\mathrm{OVA}_{254-267}$ peptide. Based on the present results, we conclude that FliC $d$ and FliC $i$ flagellins express enhanced adjuvant effects to cytotoxic responses in vaccinated mice.

Since the Salmonella flagellins differ mainly at the central hypervariable domain, which are not specifically involved in the binding of the TLR5 receptor, the differential immunological effects of FliC and FljB may not be explained solely by the recognition of the cognate TLR receptor. Indeed the recent finding that bacterial flagellins bind to a family of Nod-like receptors, such as Naip5 and Ipaf, in which flagellin-binding sites are still unknown, suggests that amino acid residues outside the strongly conserved $\mathrm{N}$ - and $\mathrm{C}$-terminal ends participate in modulation of inflammatory responses elicited by Salmonella flagellins $(1,23)$.

The potent adjuvant effects of Salmonella flagellins, both for activation of antigen-specific humoral and cellular immune responses, has received considerable attention by several research groups dealing with vaccine development. Flagellins have been employed either as an epitope carrier expressed by attenuated Salmonella vaccine strains $(14,15,22)$ as purified adjuvants admixed with different soluble antigens $(11,16)$, or as a purified hybrid protein genetically fused to the target antigen $(4,7)$. So far, the specific mechanisms by which bacterial flagellins improve the immune responses to codelivered antigens is unclear but trafficking and processing of antigens following endocytosis by antigen presenting cells is probably an important aspect (3). Such adjuvants effects would be better reasoned for antigens genetically fused to flagellin but other mechanisms may also contribute to activation and maturation of antigen presenting cells exposed simultaneously to the target antigen and soluble flagellin monomers. The question concerning the better performance of Salmonella flagellins following physical coupling to the target antigen is still open but our results shows that activation of antigen-specific $\mathrm{CD} 8^{+} \mathrm{T}$ cells as well as in vivo cytotoxic effects can be achieved in animals immunized without the need to fuse both antigen and adjuvant either by chemical or genetic approaches.

The finding that toll-like receptors ligands stimulate strong $\mathrm{T}$ cell-dependent immune responses opened up renewed perspectives for the development of therapeutic vaccines against chronic infectious diseases. The present study represents a further demonstration that Salmonella flagellins may have an important role on the field of vaccine development not only as an adjuvant for conventional antibody-dependent prophylatic vaccines but also as a component for vaccine formulation aiming eradication of invasive pathogens requiring activation of $\mathrm{CD} 8^{+}$ $\mathrm{T}$ cell-dependent immune responses.

\section{ACKNOWLEDGEMENTS}

This work was supported by CNPq (Milênio) and FAPESP grants. We thankfully acknowledge the invaluable technical assistance of Camila F.P. Calderon, Juliane A. Pereira and Aline F. Teixeira.

\section{RESUMO}

\section{Efeitos adjuvantes para células $\mathbf{T}$ citotóxicas de três flagelinas de Salmonella enterica}

As flagelinas bacterianas são importantes fatores associados à virulência e potentes indutores de resposta inflamatória em mamíferos. Estas moléculas são também investigadas como potencial adjuvante para uso em vacinas na indução de resposta imune humoral e celular para diferentes antígenos alvo. No presente estudo investigamos as propriedades adjuvantes de três tipos de flagelinas de Salmonella enterica ( $\mathrm{FliCd}$, FliCi e FljB) para um epítopo derivado da ovalbumina específico para células T CD $8^{+}$. As três flagelinas testadas induziram respostas de células T CD8 ${ }^{+}$ específicas em camundongos imunizados, porém, somente animais imunizados com as flagelinas FliC $i$ e FliC $d$ coadministradas com ovalbumina montaram resposta citotóxica específica in vivo para células-alvo pulsadas com peptídeo OVA. Os resultados apresentados indicam que flagelinas de Salmonella são dotadas de efeitos adjuvantes tipo-específico frente a células $\mathrm{T} \mathrm{CD}^{+}$in vivo, uma característica que pode gerar impactos no uso dessas proteínas como adjuvantes em vacinas profiláticas ou terapêuticas.

Palavras-chave: Salmonella, flagelina, células T citóxicas, adjuvantes, vacinas.

\section{REFERENCES}

1. Amer, A.; Franchi, L.; Kanneganti, T.D.; Body-Malapel, M.; Ozoren, N.; Brady, G. et al. (2006). Regulation of Legionella phagosome maturation and infection through flagellin and host Ipaf. J. Biol. Chem., 281: 35217-35223.

2. Barber, D.L.; Wherry, E.J.; Ahmed, R. (2003). Cutting Edge: Rapid In Vivo Killing by Memory CD8 T Cells. J. Immunol., 171: 27-31.

3. Blander, J.M.; Medzhitov, R. (2004). Regulation of phagosome maturation by signals form toll-like receptors. Science, 304: 1014-1018.

4. Cuadros, C.; Lopez-Hernandez, F.J.; Dominguez, A.L.; McClelland, M.; Lustgarten, J. (2004). Flagellin Fusion Proteins as Adjuvants or vaccines Induce Specific Immune Responses. Infect. Immun., 72: 2810-2816.

5. Ewing, W.H. (1986). Edwards and Ewing's Identification of Enterobacteriaceae. $4^{\text {th }}$ Edition. New York. Elsevier Science Publishers, 146-258.

6. Frankel, G.; Newton, S.M.C.; Schoolnik, G.K.; Stocker, B.A.D. (1989). Intragenic recombination in a flagellin gene: characterization of the H1-j gene of Salmonella Typhi. EMBO J., 8: 3149-3152. 
7. Huleatt, J.W.; Jacobs, A.R.; Tang, J.; Desai, P.; Kopp, E. B.; Huang, Y.; Song, L.; Nakaar, V.; Powell, T.J. (2006). Vaccination with recombinant fusion proteins incorporating Toll-like receptor ligands induces rapid cellular and humoral immunity. Vaccine, 1-13.

8. Iino, T.; Komeda, Y.; Kutsukake, K.; Macnab, R. M.; Matsumura, P.; Parkinson, J.S.; Simon, M.I.; Yamaguchi, S. (1988). New unified nomenclature for the flagellar genes of Escherichia coli and Salmonella Typhimurium. Microbiol. Rev., 52: 533-535

9. Lee, S.E.; Kim, S.Y.; Jeong, B.C.; Kim, Y.R.; Bae, S.J.; Ahn, O.S.; Lee, J.J.; Song, H.C.; Kim, J.M.; Choy, H.E.; Chung, S.S.; Kweon, M.N.; Rhee, J.H. (2006). A bacterial flagellin, Vibrio vulnificus FlaB, has a strong mucosal adjuvant activity to induce protective immunity. Infect. Immun., 74: 694-702.

10. Letsch, A.; Scheibenbogen, C. (2003). Quantification and characterization of specific T-cells by antigen-specific cytokine production using ELISPOT assay or intracellular cytokine staining. Methods, 31: 143-149

11. McSorley, S.J.; Ehst, B.D.; Yu, Y.; Gewirtz, A.T. (2002). Bacterial Flagellin Is an Effective Adjuvant for CD4+ T Cells In Vivo. $J$. Immunol., 169: 3914-3919.

12. Miyahira, Y.; Murata, K.; Rodríguez, D.; Rodríguez, J.R.; Esteban, M.; Rodrigue, M.M.; Zavala, F. (1995). Quantification of antigen specific $\mathrm{CD}^{+} \mathrm{T}$ cells using an ELISPOT assay. J. Immunol. Methods, 181: 45-54.

13. Murthy, K.G.; Deb, A.; Goonesekera, S.; Szabó, C.; Salzman, A.L. (2004) Identification of conserve domains in Salmonella Muenchen flagellin that are essential for its ability to activate TLR5 and to induce an inflammatory response in vitro. J. Biol. Chem., 279: 5667-5675.

14. Newton, S.M.C.; Jacob, C.O.; Stocker, B.A.D. (1989). Immune Response to Cholera Toxin Epitope Inserted in Salmonella Flagellin. Science, 244: 70-72

15. Newton, S.M.C.; Joys, T.M.; Anderson, S.A.; Kennedy, R.C.; Hovi, M.E.; Stocker, B.A.D. (1995). Expression and immunogenicity of an 18-residue epitope of HIV1 gp41 inserted in the flagellar protein of a Salmonella live vaccine. Res. Microbiol., 146: 203-206.

16. Pino, O.; Martin, M.; Michalek, S.M. (2005). Cellular mechanisms of the adjuvant activity of the flagellin component FljB of Salmonella enterica serovar Typhimurium to potentiate mucosal and systemic responses. Infect. Immun., 73: 6763-6770.

17. Ramos, H.C.; Rumbo, M.; Sirard, J.C. (2004). Bacterial flagellins: mediators of pathogenicity and host immune responses in mucosa Trends Microbiol., 12: 509-517.

18. Sbrogio-Almeida, M.E.; Ferreira, L.C.S. (2001). Flagellin expressed by live Salmonella vaccine strains induces distinct antibody responses following delivery via systemic or mucosal immunization in routes. FEMS Imunnol. Med. Microbiol., 30: 203-208.

19. Schmitt, C.K.; Darnell, S.C.; O’brien, A.D. (1996). The Attenuated Phenotype of a Salmonella typhimurium flgM Mutant Is Related to Expression of FliC Flagellin. J. Bacteriol., 178(10): 2911-2915.

20. Smith, K.D.; Andersen-Nissen, E.; Hayashi, F.; Strobe, K.; Bergman, M.A.; Barret, S. L.R.; Cookson, B.T.; Aderem, A. (2003). Toll-like receptor 5 recognizes a conserved site on flagellin required for protofilament formation and bacterial motility. Nat. Immunol., 4: 1247-1253

21. Tzelepis, F.; Persechini, P.M.; Rodrigues, M.M. (2007). Modulation of $\mathrm{CD}^{+}{ }^{+} \mathrm{T}$ Cell-Dependent Specific Cytotoxic CD8 ${ }^{+} \mathrm{T}$ Cells Differentiation and Proliferation by the Timing of Increase in the Pathogen Load. Plos ONE., 393: 4: 1-9.

22. Verma, N.K.; Ziegler, H.K.; Stocker, B.A.D.; Schoolnik, G.K. (1995). Inducion of a cellular immune response to a defined T-cell epitope as an insert in the flagellin of a live vaccine strain of Salmonella. Vaccine, 13: 235-244.

23. Zamboni, D.S.; Kobayashi, K.S.; Kohlsdorf, T.; Ogura, Y.; Long, E.M.; Vance, R.E. et al. (2006). The Birc1e cytosolic patternrecognition receptor contributes to the detection and control of Legionella pneumophila infection. Nat. Immunol., 7: 318-325. 